Dutra, F. R. \& McKibbin, J. M. (1945). F. Lab. clin. Med. 30, 301.

Richards, M. B. (1945). Brit. med. $\mathscr{Y} . \mathrm{i}, 433$.

Richards, M. B. (1946). Biochem. F. 40, liii.

Richards, M. B. (1949). Brit. $\mathcal{~}$. Nutrit. 3, 132.

Stoerk, H. C. (1946). Proc. Soc. exp. Biol., N.Y., 62, 90.

Stoerk, H. C., Eisen, H. N. \& John, H. M. (1947). F. exp. Med. 85, 365.

Stoerk, H. C. \& Zucker, T. F. (1944). Proc. Soc. exp. Biol., N.Y., 56, 151.

\title{
Influence of the Extraction Rate of Flour on Conditioned Pyridoxin Deficiency in Rats
}

\author{
BY MARION B. RICHARDS \\ Rowett Research Institute, Bucksburn, Aberdeenshire
}

(Received 30 August 1948)

In experiments previously reported (Richards, 1945), a conditioned pyridoxin deficiency was produced in rats with a diet of high vitamin $B_{1}$ content. The diet was satisfactory for growth and reproduction, but during lactation convulsive fits characteristic of pyridoxin deficiency were observed in the young rats. The fits were prevented by giving the does $40 \mu \mathrm{g}$. of pyridoxin daily from parturition onwards. The basal diet contained $60.9 \%$ of white flour of approx. $70 \%$ extraction, and it was found that the fits were prevented also when $85 \%$ extraction flour was substituted for the white flour. Fig. I gives the weight graphs of litters which show the effect of this substitution on a few does in groups V and VI of the original experiments (Richards, 1945), in which the vitamin $B_{1}$ supplements were, respectively, 0.76 and $5.15 \mathrm{mg} / 100 \mathrm{~g}$. diet, and the calcium supplement $0.54 \mathrm{~g}$. calcium carbonate/ $100 \mathrm{~g}$. diet. In group $\mathrm{V}$, with a medium vitamin $B_{1}$ content, in which fits had been observed frequently in the litters of does on the white flour diet, does 321 and 352 on $85 \%$ extraction flour reared litters free from fits to a good weaning weight. A similar result was obtained even in group VI with the highest intake of vitamin $B_{1}$, where the weight graph of the litter of doe 475 on $85 \%$ extraction flour makes a striking contrast with the almost complete failure of the litters on the white flour diet.

As a sequel to this observation on the effect of substituting $85 \%$ extraction flour for white flour in the diet with the imbalance of B-vitamins, a series of experiments was carried out with flours whose extraction rate ranged from 72 to $85 \%$, all prepared from the same sample of wheat. The studies on growth, reproduction and lactation were continued eventually to the fourth generation. In a preliminary communication (Richards, 1946) a brief report was given of the growth test and first breeding test of first generation rats on the various diets, and another communication (Richards, 1947) outlined the results of the breeding tests of the second and third generation animals. The present paper gives these results in greater detail, including the effect on thymus development in the weanlings, and extends them to include the fourth generation. 


\section{METHODS}

The basal diet used throughout the experiments had the following percentage composition: wheat flour $60 \cdot 9$, casein (lactic, unextracted) $23 \cdot 9$, dried brewer's yeast, $1 \cdot 9$; vitaminized margarine $10 \cdot 8$, McCollum's salt mixture no. 185 with ferric citrate $2 \cdot 0$, and calcium carbonate 0.5 . The following additions, in $\mathrm{mg} / \mathrm{1} / 00 \mathrm{~g}$. diet were made to

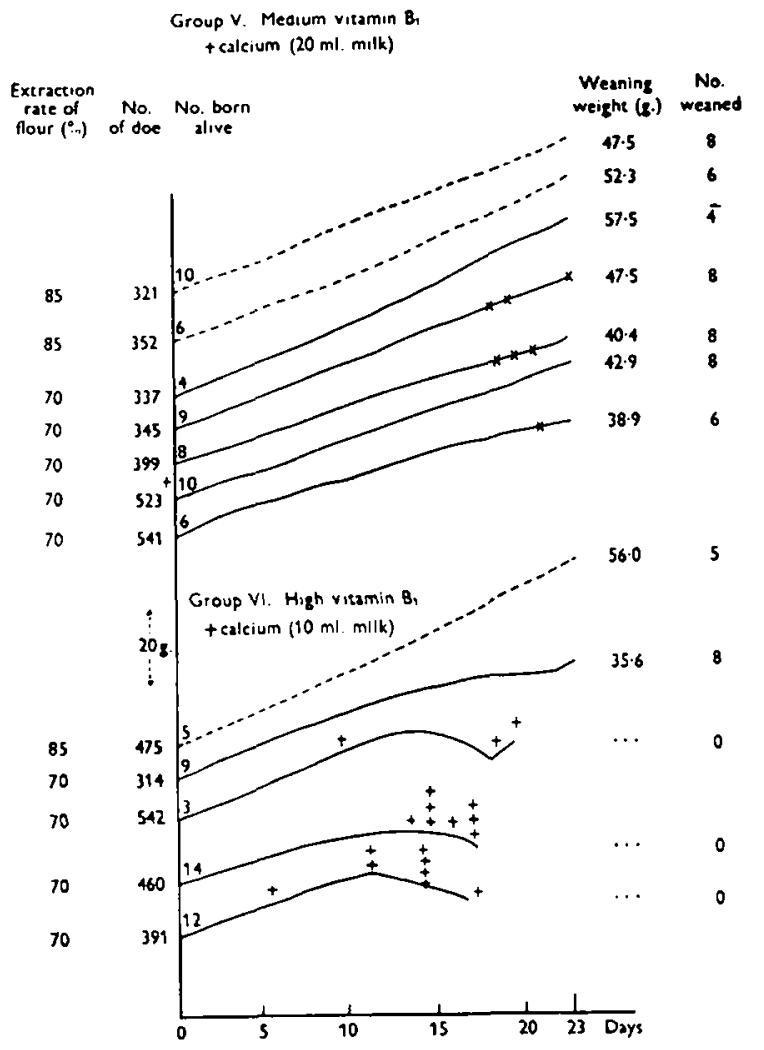

Fig. x. Preliminary experiment showing beneficial effect on lactation of substituting $85 \%$ extraction flour for $70 \%$ extraction flour in a diet with excess of vitamin $B_{1}$. Graphs show average weight per rat from birth onwards for individual litters (daily weighings). $x$ denotes fits in sucklings. + denotes death of a suckling. - - - , 85\% extraction flour. - $70 \%$ extraction flour.

- Litters larger than eight were always reduced to eight 2 days after birth. At this stage of the work litters smaller than eight were not made up to eight, as was done later.

the above diet: $\mathrm{KI}, 0 \cdot 368 ; \mathrm{MnSO}_{4} \cdot 4 \mathrm{H}_{2} \mathrm{O}, 3 \cdot 68$; and vitamin $\mathrm{B}_{1}, 5 \cdot 08$. Vitamins $\mathrm{A}, \mathrm{D}$ and $\mathrm{E}$ were supplied by dissolving $\mathrm{I} \mathrm{g}$. $\alpha$-tocopherol acetate in $50 \mathrm{ml}$. radiostoleum (British Drug Houses Ltd.) and incorporating this solution in the margarine in the proportion of $\mathrm{I} \mathrm{ml}$. to $90 \mathrm{~g}$. The diet was given as a stiff paste, the requisite amounts of $\mathrm{KI}, \mathrm{MnSO}_{4}$ and vitamin $\mathrm{B}_{1}$ being added to the water used in making up the daily ration. The food was always given to appetite. From mating onwards the animals received in addition $20 \mathrm{ml}$. milk/head daily.

Four groups of rats were given diets which differed only in the extraction rate of the 
flour included; these groups are designated ' 72 ', ' 77 ', ' 80 ' and ' 85 ' according to the extraction rate. An additional group, having the $72 \%$ extraction flour, was given a supplement of $40 \mu \mathrm{g}$. of pyridoxin daily, and is designated group ' 72 plus pyridoxin'.

The amount of vitamin $B_{1}$ added to the diet was the same as the high-level addition used in the original experiments (Richards, 1945). This high-level addition was used throughout the present series of experiments except that, in the fourth generation, group 85 was divided into three subgroups, $85 \mathrm{H}, 85 \mathrm{M}$ and $85 \mathrm{~L}$, receiving high, medium and low levels of vitamin $B_{1}$, respectively. In group $85 \mathrm{H}$ the amount of vitamin $B_{1}$ added was $5.08 \mathrm{mg} . / 100 \mathrm{~g}$. diet, as in the breeding tests with the three previous generations. In groups $85 \mathrm{M}$ and $85 \mathrm{~L}$ the amounts of vitamin $\mathrm{B}_{1}$ added per $100 \mathrm{~g}$. diet were $0.75^{1}$ and $0.270 \mathrm{mg}$., respectively.

Growth tests and breeding tests were carried out in the usual way (Richards, 1949), the young being weaned at 23 days of age.

\section{RESULTS}

\section{Growth tests}

The results of the growth tests are summarized in Table $\mathrm{I}$ and in Figs. 2 and 3, which show diagrammatically the average weight increase per rat in each group for 8 successive weeks from weaning in each of the four generations.

In the first generation test in which the animals were stock weanlings of approxi-

Table I. Average weight increase for 8 weeks from weaning of four generations of rats receiving diets high in vitamin $B_{1}$ and containing flours of different rates of extraction

\begin{tabular}{|c|c|c|c|c|c|c|c|c|c|}
\hline \multirow{3}{*}{$\begin{array}{l}\text { Extraction } \\
\text { rate of } \\
\text { flour for } \\
\text { group } \\
(\%)\end{array}$} & \multirow{3}{*}{$\begin{array}{c}\text { Genera- } \\
\text { tion } \\
\text { no. }\end{array}$} & \multicolumn{4}{|c|}{ Males } & \multicolumn{4}{|c|}{ Females } \\
\hline & & \multicolumn{2}{|c|}{ Wt. } & \multirow{2}{*}{$\begin{array}{l}\text { No. } \\
\text { of } \\
\text { rats }\end{array}$} & \multirow{2}{*}{$\begin{array}{c}\text { Weekly } \\
\text { increase } \\
\text { in weeks } \\
2-8 \\
\text { (g.) }\end{array}$} & \multicolumn{2}{|c|}{ Wt. } & \multirow{2}{*}{$\begin{array}{l}\text { No. } \\
\text { of } \\
\text { rats }\end{array}$} & \multirow{2}{*}{$\begin{array}{c}\text { Weekly } \\
\text { increase } \\
\text { in weeks } \\
2-8 \\
\text { (g.) }\end{array}$} \\
\hline & & $\begin{array}{c}\text { Initial } \\
\text { (g.) }\end{array}$ & $\begin{array}{c}\text { Final } \\
(\mathrm{g} .)\end{array}$ & & & $\begin{array}{c}\text { Initial } \\
(\mathrm{g} .)\end{array}$ & $\begin{array}{l}\text { Final } \\
\text { (g.) }\end{array}$ & & \\
\hline \multirow[t]{2}{*}{72} & $\begin{array}{l}\mathbf{1} \\
2\end{array}$ & $\begin{array}{l}49 \cdot 3 \\
40 \cdot 8\end{array}$ & $\begin{array}{l}240 \cdot 3 \\
191 \cdot 3\end{array}$ & $\begin{array}{r}6 \\
10\end{array}$ & $\begin{array}{l}23 \cdot 9 \\
20 \cdot 0\end{array}$ & $\begin{array}{l}46 \cdot 5 \\
39 \cdot I\end{array}$ & $\begin{array}{l}176 \cdot 3 \\
159 \cdot 6\end{array}$ & $\begin{array}{l}8 \\
7\end{array}$ & $\begin{array}{l}15.6 \\
15.6\end{array}$ \\
\hline & $\begin{array}{l}3 \\
4\end{array}$ & $32 \cdot 0$ & 207.5 & $\stackrel{2}{-}^{2}$ & $23 \cdot 7$ & $\begin{array}{c}28 \cdot 5 \\
-\end{array}$ & $146 \cdot 5$ & $\stackrel{2}{-}^{2}$ & 15.7 \\
\hline \multirow[t]{2}{*}{77} & $\begin{array}{l}\text { I } \\
2 \\
3\end{array}$ & $\begin{array}{l}48 \cdot 5 \\
44 \cdot 6 \\
46 \cdot 0\end{array}$ & $\begin{array}{l}248 \cdot 9 \\
215 \cdot 1 \\
244 \cdot 8\end{array}$ & $\begin{array}{r}6 \\
10 \\
12\end{array}$ & $\begin{array}{l}25 \cdot 3 \\
23 \cdot 0 \\
26 \cdot 5\end{array}$ & $\begin{array}{l}47 \cdot 0 \\
43 \cdot 0 \\
43^{\circ} \cdot\end{array}$ & $\begin{array}{l}199 \cdot 3 \\
170 \cdot 5 \\
176 \cdot 0\end{array}$ & $\begin{array}{r}8 \\
\text { II } \\
\text { II }\end{array}$ & $\begin{array}{l}18.5 \\
16.6 \\
16.7\end{array}$ \\
\hline & 4 & - & - & - & - & - & - & - & - \\
\hline \multirow[t]{3}{*}{80} & $\begin{array}{l}1 \\
2\end{array}$ & $\begin{array}{l}49 \cdot 8 \\
47 \cdot 0\end{array}$ & $\begin{array}{l}253.5 \\
215 \cdot 2\end{array}$ & $\begin{array}{r}6 \\
10\end{array}$ & $\begin{array}{l}25 \cdot 9 \\
22 \cdot 8\end{array}$ & $\begin{array}{l}46 \cdot 6 \\
43 \cdot 6\end{array}$ & $\begin{array}{l}197.5 \\
167.3\end{array}$ & $\begin{array}{r}8 \\
10\end{array}$ & $\begin{array}{l}18 \cdot 5 \\
16 \cdot 8\end{array}$ \\
\hline & 3 & $39^{\cdot I}$ & 213.5 & II & $23 \cdot 6$ & $37 \cdot 2$ & 164.2 & 9 & $16 \cdot 7$ \\
\hline & 4 & $42 \cdot 3$ & $271 \cdot 3$ & 6 & $30 \cdot 6$ & 37.7 & $178 \cdot 2$ & 9 & $18 \cdot I$ \\
\hline \multirow[t]{4}{*}{85} & I & 49.0 & $275 \cdot 8$ & 6 & $28 \cdot 8$ & $46 \cdot 8$ & $204 \cdot 6$ & 8 & $19 \cdot 0$ \\
\hline & 2 & $52 \cdot 5$ & $229 \cdot 3$ & 13 & $24 \cdot 0$ & $50 \cdot 4$ & 180.5 & 12 & 16.9 \\
\hline & 3 & $41 \cdot 7$ & $234 \cdot 3$ & 13 & $26 \cdot 2$ & $39 \cdot 7$ & $170 \cdot 2$ & 13 & $17 \cdot 1$ \\
\hline & 4 & $43^{\circ} \cdot 4$ & 260.0 & 4 & $29 \cdot 2$ & $4 I \cdot 4$ & 185.1 & II & 18.7 \\
\hline \multirow{4}{*}{$\stackrel{72+}{\text { pyridoxin }}$} & 1 & $49 \cdot 2$ & $247 \cdot 6$ & 6 & $24 \cdot 8$ & $46 \cdot 5$ & 195.6 & 8 & 18.4 \\
\hline & 2 & 48.8 & $220 \cdot 4$ & 8 & $23 \cdot 2$ & $47 \cdot 3$ & $189 \cdot 1$ & II & 18.8 \\
\hline & 3 & 44.9 & $237 \cdot 3$ & 8 & $26 \cdot 0$ & $43 \cdot 7$ & I88.2 & II & 18.7 \\
\hline & 4 & $39 \cdot 6$ & 171.0 & 4 & 17.7 & $37 \cdot 2$ & 153.6 & 8 & 15.7 \\
\hline
\end{tabular}


mately equal initial weights, there were considerable differences in growth rate among the different groups. For the males the weight increases in groups 72,72 plus pyri-

Males

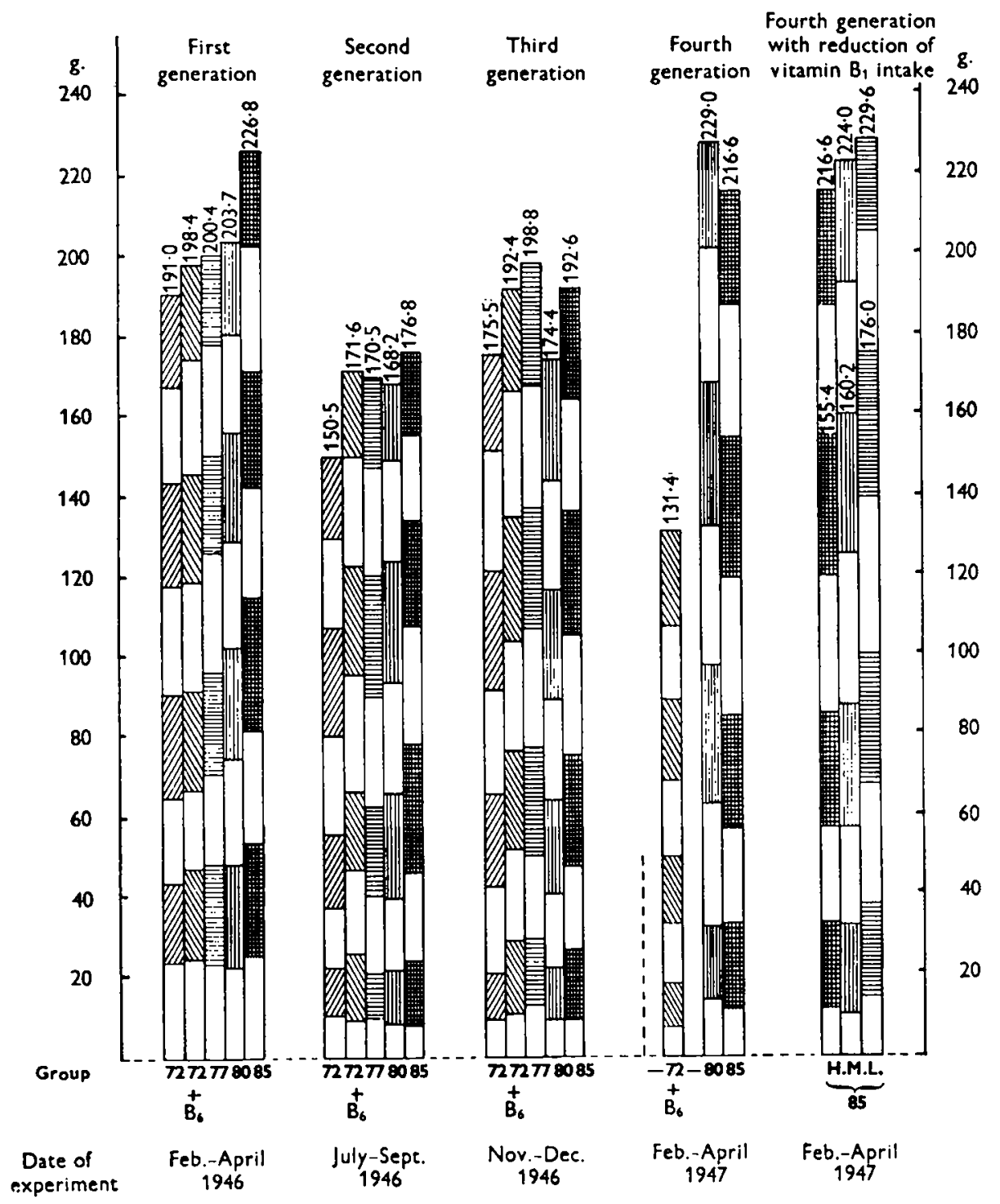

Fig. 2. Cumulative weekly increase in weight (g.) for 8 weeks from weaning of four generations of male rats receiving flours of different extraction rates in a diet high in vitamin $B_{1}$. Each alternating, shaded or unshaded, block in the vertical columns represents the average weight increase of a group for I week, the total increase for 8 weeks being shown at the top of the column. The three columns on the right of the diagram represent the weight increase of groups of rats receiving $85 \%$ extraction flour with high, medium and low intakes of vitamin $B_{1}$.

doxin, 77,80 and 85 averaged $191 \cdot 0,198.4,200.4,203.7$ and $226.8 \mathrm{~g}$., respectively. For the females the corresponding increases were $129^{\circ} 8,149^{\cdot 1}, 152 \cdot 3,150 \cdot 9$ and $157^{\cdot} 8 \mathrm{~g}$. Thus in both males and females the highest weight increase was found in group $8 \mathbf{5}$ and 
the lowest in group 72, but in the males the greatest difference between adjacent groups was that between groups 80 and 85 , whereas in the females the greatest difference occurred between groups 72 and 72 plus pyridoxin. This may possibly indicate a greater requirement of pyridoxin by the females during the period of rapid growth (cf. Richards, 1949). No definite reason can be given for the superior value for growth of

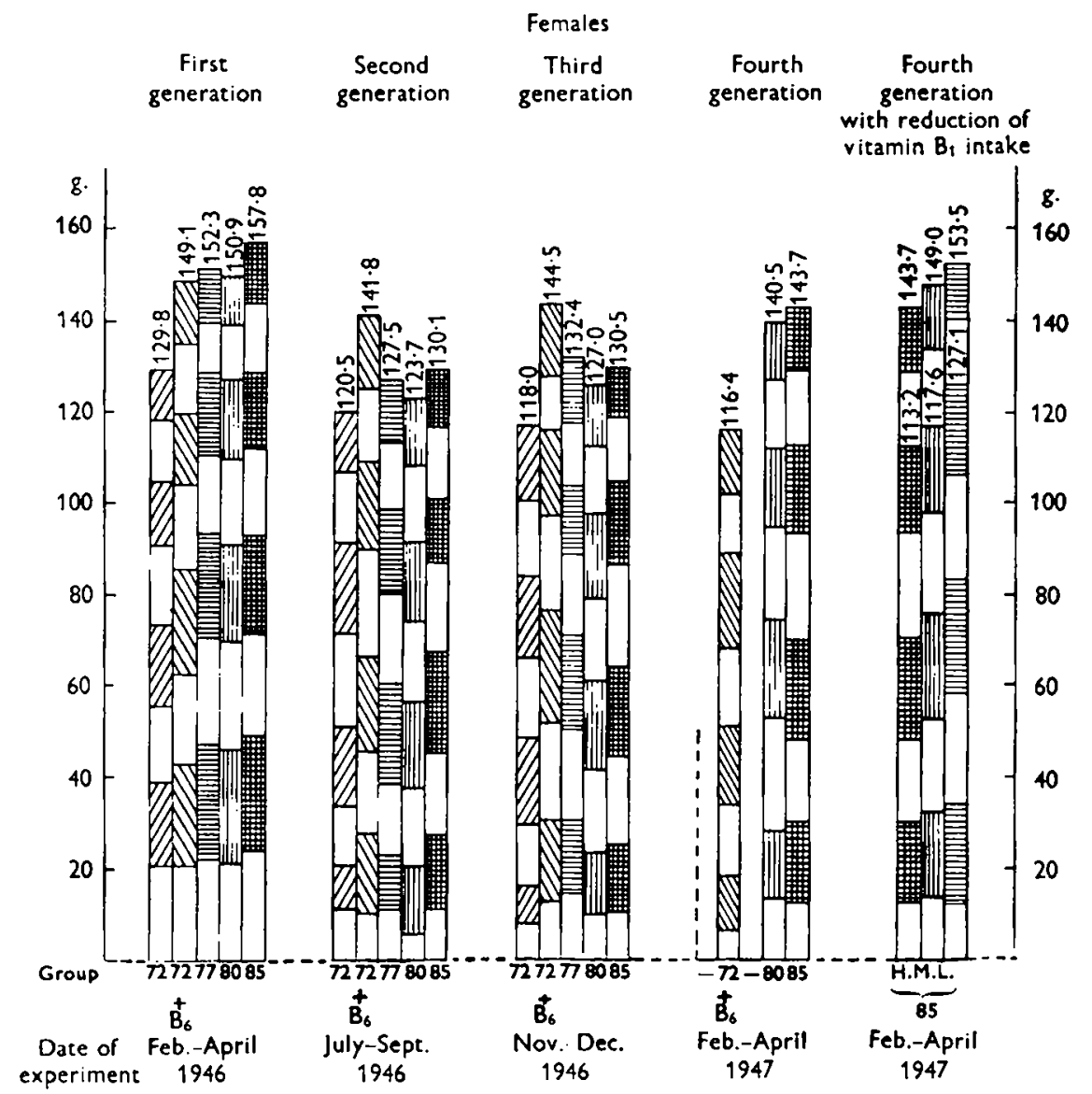

Fig. 3. Cumulative weekly increase in weight (g.) for 8 weeks from weaning of four generations of female rats receiving flours of different extraction rates in a diet high in vitamin $B_{1}$. Each alternating, shaded or unshaded, block in the vertical columns represents the average weight increase of a group for I week, the total increase for 8 wecks being shown at the top of the column. The three columns on the right of the diagram represent the weight increase of groups of rats receiving $85 \%$ extraction flour with high, medium and low intakes of vitamin $B_{1}$.

the higher extraction flours. It might have been due to their greater palatability, as some workers have suggested, or to an effect on appetite, indicative of improved wellbeing in the animal. In view of the high proportion of casein in the diet the effect is not likely to have been due to any contribution of more or better protein. The better growth of the females receiving the pyridoxin supplement with $72 \%$ extraction flour suggests that the improvement may have been due to readjustment, or partial readjustment, of the balance of $B$-vitamins, disturbed by the high intake of vitamin $B_{1}$. 
The growth-promoting effect of pyridoxin was evident in both males and females in the second and third generation tests, in which the males of group 72 plus pyridoxin showed almost the same weight increase as those of group 85, and the females of group 72 plus pyridoxin considerably surpassed those of group 85 . In the fourth generation tests, however, the animals of group 72 plus pyridoxin fell far behind those of groups 80 and 85 . This was presumably due to the cumulative effect of other deficiencies in the diet, possibly conditioned deficiencies of vitamin B-complex factors other than pyridoxin.

It may be well to emphasize that too much stress should not be laid on growth records alone for assessing the nutritive value of a diet. The present series of experiments gives ample evidence that a diet which is apparently adequate for growth may prove quite inadequate for successful reproduction and lactation. Thus, the third generation females of groups 77,80 and 85 , whose behaviour in the growth test was almost identical, were found later to show very marked differences in breeding performance.

\section{Effect of reducing the vitamin $B_{1}$ intake on the growth of the fourth generation rats}

The number of weanlings available for the fourth generation test in group 85 was large enough to permit their division into the three subgroups $85 \mathrm{H}, 85 \mathrm{M}$ and $85 \mathrm{~L}$, with high, medium and low additions of vitamin $B_{1}$ as described above. The results of the growth test for these subgroups, in which the initial weights were almost equal, are shown in the right-hand columns of Figs. 2 and 3. They indicate a distinct tendency, in both males and females, towards improvement in the growth rate with reduction of the vitamin $B_{1}$ supplement.

\section{First generation}

\section{Breeding tests}

The rats were mated after 8 weeks of the growth test, and the results of the first breeding test, previously reported in brief (Richards, 1946), are shown graphically in Fig. 4, which gives the weight graphs for the individual litters of groups 72, 77, 80 and 85 , and indicates approximately the number of fits observed. From the diminution in the number of fits, and the increase in the weaning weights, it is evident that the conditioned pyridoxin deficiency decreased in intensity as the extraction rate of the flour was raised. Of seven litters in group 72 all showed severe fits, all of one litter dying before weaning age ( 23 days), and another litter having only one survivor. In group 77 fits were observed in six of seven litters, repeatedly in four of the litters. In group 80 fits were observed in only two of seven litters, but they were severe in one litter, all of which died before weaning. In group 85 no fits were observed, and eight litters were reared to weaning without a death. The mean weaning weight of group 85 was greater by $10.5 \mathrm{~g}$./rat than that of group 72 . In group 72 plus pyridoxin, six litters were reared successfully without fits (Fig. 8).

These experiments were carried out before Mellanby (1946, 1947) drew attention to the dangers arising from the use of flour bleached with agene (nitrogen trichloride) in 
the feeding of dogs and ferrets. The $72 \%$ extraction flour used in the rat experiments described in the present paper was not treated with agene or any other chemical. The fits observed in the young were not, therefore, due to any effect of agene, and the absence of fits in the litters of does which received the same diet with added pyridoxin indicated that they were due to pyridoxin deficiency. The fits in these rats must therefore be distinguished from the convulsive fits found by Mellanby in dogs and ferrets fed on flour bleached with agene.
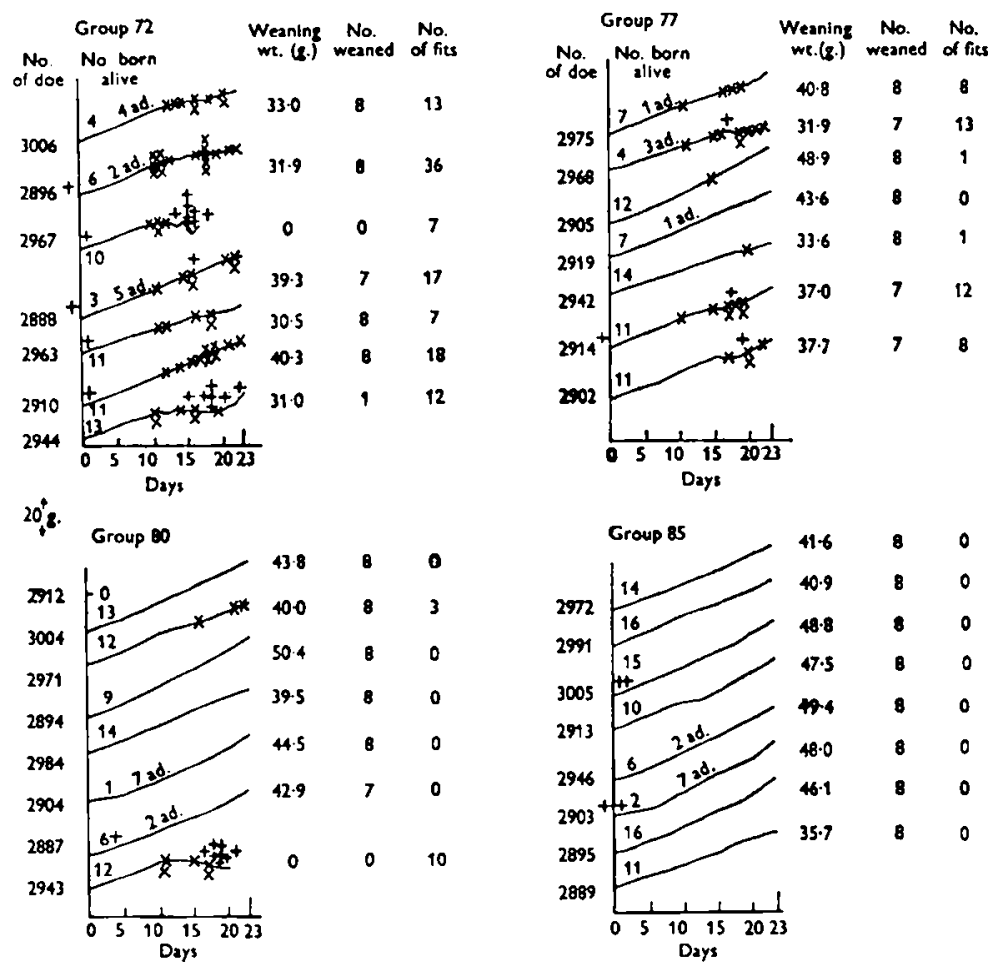

Fig. 4. First generation. Effect on reproduction and lactation of varying the extraction rate of flour in a diet high in vitamin $B_{1}$. Graphs show average weight per rat from birth onwards for individual litters (daily weighings). Ad. adopted. + above the graph denotes death of a suckling, stillbirths being indicated by + to left of vertical axis. $x$ denotes fits in sucklings, each $x$ representing three fits or fewer. The average weaning weight, number of young reared, and total number of fits observed, are shown to the right of each graph.

- Litters larger than eight were always reduced to eight 2 days after birth. On the same day litters smaller than eight were made up to eight if suitable young were available for adoption.

Further matings of the same does showed that there was no progressive deterioration in the later litters, but rather a tendency towards improvement, as shown by a decrease in the number of observed fits and an increase in weaning weight. The results of three successive matings of the first generation does are summarized in Table 2. There was a marked decrease in the number of observed fits in the second litters of group 77 , although little improvement was seen in those of group 72 but, in the third litters, group 72 also showed a considerable reduction in the number of fits. The improvement 
Vol. 3

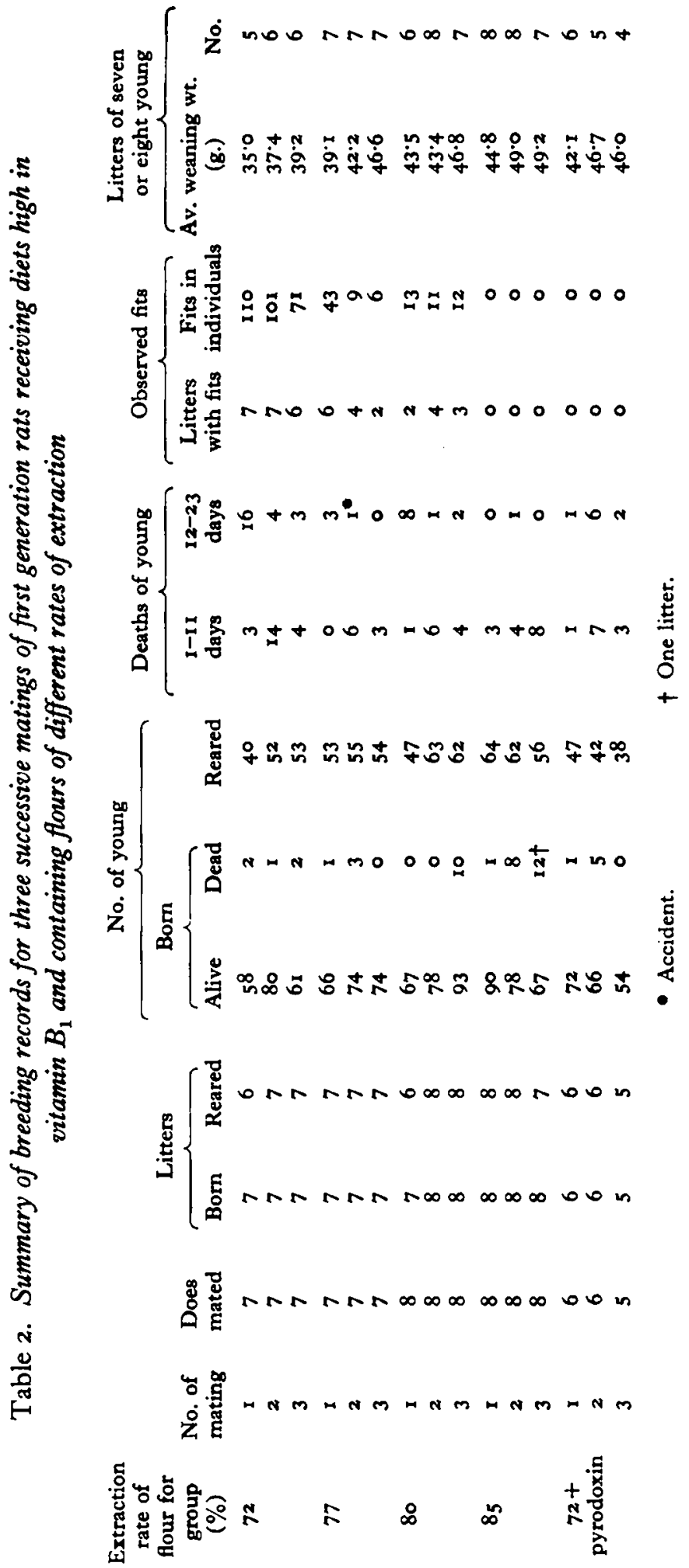


was even greater than the figures indicate, since fifty-three of the seventy-one fits were recorded in two litters. Among the remaining five litters only eighteen fits were observed. The most probable explanation of this improvement would appear to be the increasing maturity of the doe in successive lactations. When first mated the rats were 79 days old and still adolescent, so that the does' requirements of pyridoxin for their own growth would compete with the requirements for lactation. In later matings, when the does were more fully grown, presumably a greater proportion of the pyridoxin of the diet would be available for the needs of the sucklings. Consistent with this explanation is the observation that in group 72 , in which the conditioned deficiency was most severe at the first mating, there was no marked improvement until the third mating, whereas in group 77 , where the deficiency was less severe, the improvement was apparent even in the litters of the second mating.

Table 3. Breeding records of does reared from weaning on experimental diets high in vitamin $B_{1}$ and containing flours of different rates of extraction compared with those of does reared on a stock diet and transferred to the experimental diets before mating

\begin{tabular}{|c|c|c|c|c|c|c|c|c|c|}
\hline \multirow[b]{3}{*}{$\begin{array}{l}\text { Extraction } \\
\text { rate of flour } \\
\text { for group } \\
\quad(\%)\end{array}$} & & \multicolumn{4}{|c|}{$\begin{array}{l}\text { Does reared from weaning } \\
\text { on experimental diets }\end{array}$} & \multicolumn{4}{|c|}{$\begin{array}{l}\text { Does reared on stock diet and } \\
\text { transferred to experimental diets } \\
14-18 \text { days before mating }\end{array}$} \\
\hline & & \multicolumn{2}{|c|}{ Litters } & \multirow[b]{2}{*}{$\begin{array}{l}\text { Av. } \\
\text { no. of } \\
\text { fits/litter }\end{array}$} & \multirow[b]{2}{*}{$\begin{array}{l}\text { Av. } \\
\text { weaning } \\
\text { wt. } \\
\text { (g.) }\end{array}$} & \multicolumn{2}{|c|}{ Litters } & \multirow[b]{2}{*}{$\begin{array}{c}\text { Av. } \\
\text { no. of } \\
\text { fits/litter }\end{array}$} & \multirow[b]{2}{*}{$\begin{array}{l}\text { Av. } \\
\text { weaning } \\
\text { wt. } \\
\text { (g.) }\end{array}$} \\
\hline & $\begin{array}{l}\text { No. of } \\
\text { mating }\end{array}$ & $\begin{array}{l}\text { Total } \\
\text { no. }\end{array}$ & $\begin{array}{l}\text { No. } \\
\text { with } \\
\text { fits }\end{array}$ & & & $\begin{array}{c}\text { Total } \\
\text { no. }\end{array}$ & $\begin{array}{l}\text { No. } \\
\text { with } \\
\text { fits }\end{array}$ & & \\
\hline 72 & $\begin{array}{l}I \\
2\end{array}$ & $\begin{array}{l}7 \\
7\end{array}$ & $\begin{array}{l}7 \\
7\end{array}$ & $\begin{array}{l}15.7 \\
14.4\end{array}$ & $\begin{array}{l}34^{\circ} 3 \\
35^{\circ} 0\end{array}$ & $\begin{array}{l}5 \\
5\end{array}$ & $\begin{array}{l}3 \\
3\end{array}$ & $\begin{array}{l}16 \cdot 7 \\
11 \cdot 0\end{array}$ & $\begin{array}{l}39 \cdot 3 \\
45^{\cdot 1}\end{array}$ \\
\hline 77 & $\begin{array}{l}\text { I } \\
2\end{array}$ & $\begin{array}{l}7 \\
7\end{array}$ & $\begin{array}{l}6 \\
4\end{array}$ & $\begin{array}{l}7 \cdot 2 \\
2 \cdot 3\end{array}$ & $\begin{array}{l}39 \cdot 1 \\
42 \cdot 2\end{array}$ & $\begin{array}{l}4 \\
3\end{array}$ & $\begin{array}{l}0 \\
0\end{array}$ & $\begin{array}{l}0 \\
0\end{array}$ & $\begin{array}{l}44.0 \\
45.9\end{array}$ \\
\hline 80 & $\begin{array}{l}\mathbf{I} \\
2\end{array}$ & $\begin{array}{l}7 \\
8\end{array}$ & $\begin{array}{l}2 \\
4\end{array}$ & $\begin{array}{l}6 \cdot 7 \\
2 \cdot 8\end{array}$ & $\begin{array}{l}43 \cdot 5 \\
43 \cdot 4\end{array}$ & $\begin{array}{l}5 \\
5\end{array}$ & $\begin{array}{l}2 \\
0\end{array}$ & $\begin{array}{l}2 \cdot 5 \\
0\end{array}$ & $\begin{array}{l}46 \cdot 3 \\
50 \cdot 4\end{array}$ \\
\hline 85 & I & $\begin{array}{l}8 \\
8\end{array}$ & $\begin{array}{l}0 \\
0\end{array}$ & $\begin{array}{l}0 \\
0\end{array}$ & $\begin{array}{l}44 \cdot 8 \\
49 \cdot 0\end{array}$ & $\begin{array}{l}5 \\
3\end{array}$ & $\begin{array}{l}0 \\
0\end{array}$ & $\begin{array}{l}\circ \\
0\end{array}$ & $\begin{array}{l}46 \cdot 3 \\
48 \cdot 5\end{array}$ \\
\hline $\begin{array}{c}72+ \\
\text { pyridoxin }\end{array}$ & $\begin{array}{l}\mathbf{1} \\
\mathbf{2}\end{array}$ & $\begin{array}{l}6 \\
6\end{array}$ & $\begin{array}{l}0 \\
0\end{array}$ & $\begin{array}{l}0 \\
0\end{array}$ & $\begin{array}{l}42 \cdot 1 \\
46 \cdot 7\end{array}$ & $\begin{array}{l}5 \\
3\end{array}$ & $\begin{array}{l}0 \\
0\end{array}$ & $\begin{array}{l}0 \\
0\end{array}$ & $\begin{array}{l}43 \cdot 3 \\
48 \cdot 1\end{array}$ \\
\hline
\end{tabular}

During the first-generation breeding test a problem of technique was investigated which arose in the course of previous experiments (Richards, 1945). It then appeared that the litters of stock does which, from shortly before mating, had received the experimental diet with white flour and high vitamin $B_{1}$ intake, were as susceptible to fits as those of does which had been reared from weaning on the experimental diet. This was of interest, since it would shorten the experiments considerably if the preliminary growth period could be omitted. To check this point groups, consisting of five stock does each, were given the diets containing the different extraction flours for $1_{4}-18$ days before mating. From the breeding records, which are summarized in Table 3 , it will be seen that the results obtained with the stock adults were less satisfactory than with the young does reared from weaning on the experimental diets, the distinctions between the different groups being less clearly marked with the stock rats. 
In group 72 all litters from the young experimental does showed fits, from both the first and second matings, but of five litters from the stock adults two showed no fits, from either the first or second mating. In group 77 from the first mating six of seven litters from the experimental does showed fits, and four of seven from the second mating; in the litters from the stock adults no fits were observed. In group 80, two of seven litters from the first mating of the young experimental does, and four of eight from the second mating, were seen to have fits; two of the litters from the first mating of the stock adults showed fits, but none from the second. In these three groups, 72, 77 and 80 , moreover, the weaning weights of the litters from the stock adults were appreciably higher than those of the litters from the young experimental does. In groups 85 and 72 plus pyridoxin the results with the stock adults were similar to those obtained with the younger rats. No fits were observed, and the weaning weights of the litters were about the same.

The effects of the dietary imbalance as evinced by the records during breeding and lactation were thus intensified by dietary imbalance during the period of growth, so that more conclusive results could be obtained from one mating of does reared from weaning on the experimental diet, than from two matings of does reared on stock diet and then transferred to the experimental diet.

\section{Second generation}

Although deterioration was not evident in the later matings of the first generation, the results of the second-generation breeding tests, which are summarized in Figs. 5 and 8 and Table 4 , revealed considerable deterioration in all groups except group 85 . In this test the does were mated only once, except those in group 72 and those in other groups which failed with their first litters. Deterioration was very marked in group $\mathbf{7 2 .}$ The group contained eight does, of which seven were twice mated, but of seventyseven young born alive only sixteen were reared. Several litters died within 2 or 3 days of birth, but about half the deaths occurred in the second half of the suckling period, when fits were frequent in the litters. Deterioration, though less marked than in group 72 , was evident in groups 77,80 and 72 plus pyridoxin, in each of which there were cases of failure. In group 77 , which contained eleven does, nine litters were reared, but two does, twice mated, failed to rear any of the twenty-seven young born alive. In group 80 with ten does, six litters were reared, but four does failed to suckle any young from six litters born. In the $\mathbf{7 2}$ plus pyridoxin group seven litters were reared (Fig. 8), but three of the does failed to rear any of the fifty-one rats born alive in six litters. These failures in group 72 plus pyridoxin were mostly due to an unusual form of cannibalism observed only in this group. The doe mutilated the live young so that death frequently took place from haemorrhage. In group 85 there was little evidence of deterioration except for a slight decrease in the weaning weights of the young. Each of the twelve does in the group reared a litter, all adopted in one case, and no fits were observed.

Occurrence of fits in rats of the second generation when adult. A further sign of deterioration in the second generation was the occurrence of fits in the adult rats. No fits had been observed in adults of the first generation, although many of the does were kept on the diets for up to II months, but in several animals, both male and female, of the 


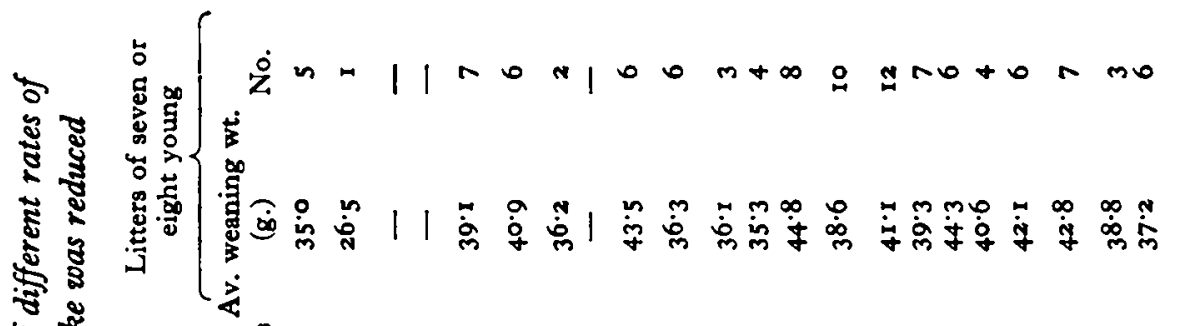

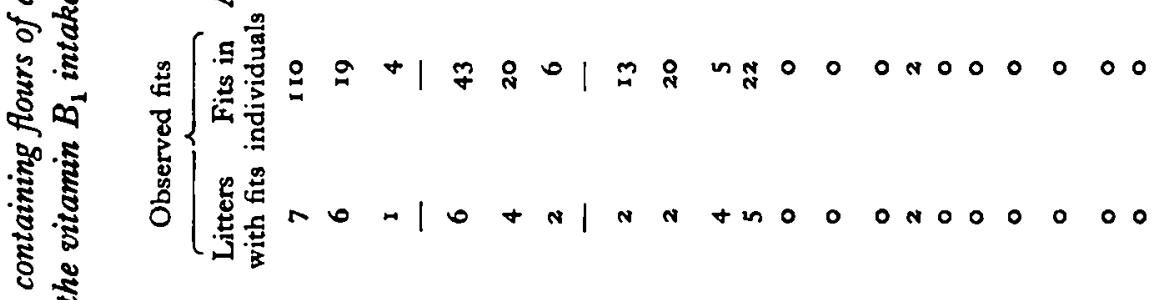


second generation fits were observed. Thus, doe 24 in group 72 had fits 4 days after the birth of a litter, and doe I 70 in group 77 had fits a few hours after the birth of her second litter. Neither of these does succeeded in rearing any young. This is in accordance with a previous finding (Richards, 1949) that does subject to fits appeared to be incapable of rearing their litters. Doe 24 , which was about 4 months old when fits were first seen,
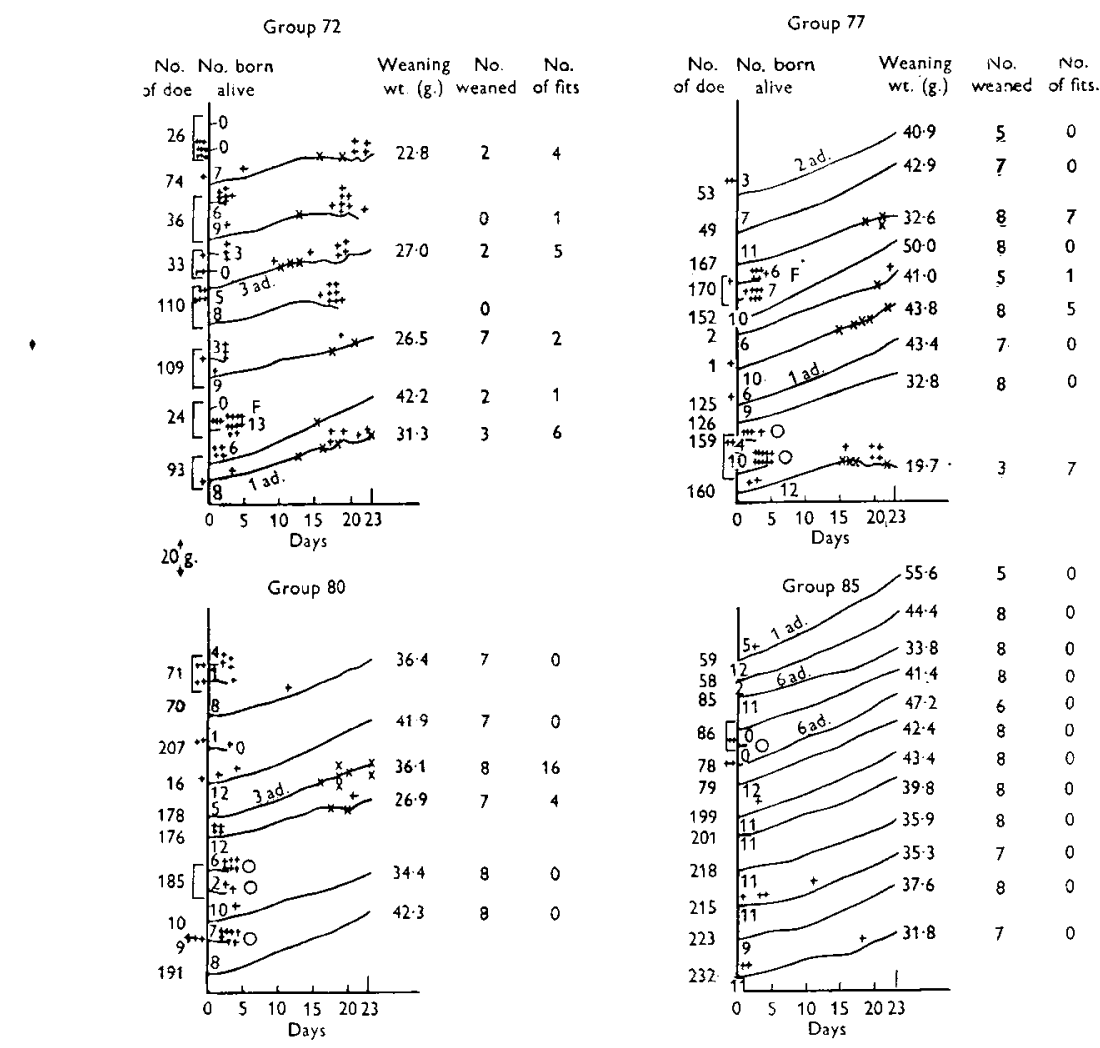

Fig. 5. Second generation. Effect on reproduction and lactation of varying the extraction rate of flour in a diet high in vitamin $B_{1}$. Graphs show average weight per rat from birth onwards for individual litters (daily weighings).* Ad. adopted. + above the graph denotes death of a suckling, stillbirths being indicated by + to left of vertical axis. $x$ denotes fits in sucklings, each $\times$ representing three fits or fewer. $F$ denotes fits in doe. The average weaning weight, number of young reared, and total number of fits observed, are shown to the right of each graph.

* See footnote to Fig. 4.

produced no further litter and had to be killed at the age of $5 \frac{1}{2}$ months after suffering repeated violent fits. In addition to these females, two males in group 77 and one male in group 80 had fits at the age of $3 \frac{1}{2}-4 \frac{1}{2}$ months. None of these adults had been observed to have fits when they were sucklings. The first generation animals were weanlings taken from stock, and the absence of fits in the adults of that generation, coupled with their occurrence in the adults of the second generation, seems to indicate the possible presence of hidden defects in the litters of the first generation, even when fits were not observed. 


\section{Third generation}

The results of the breeding tests in the third generation are summarized in Figs. 6 and 8 and in Table 4.

In the third generation only two does were available to represent group 72 . In the preceding generation, the weanlings of the first litters had been used for thymus-weight determinations, and the second matings were almost all failures. From these two does

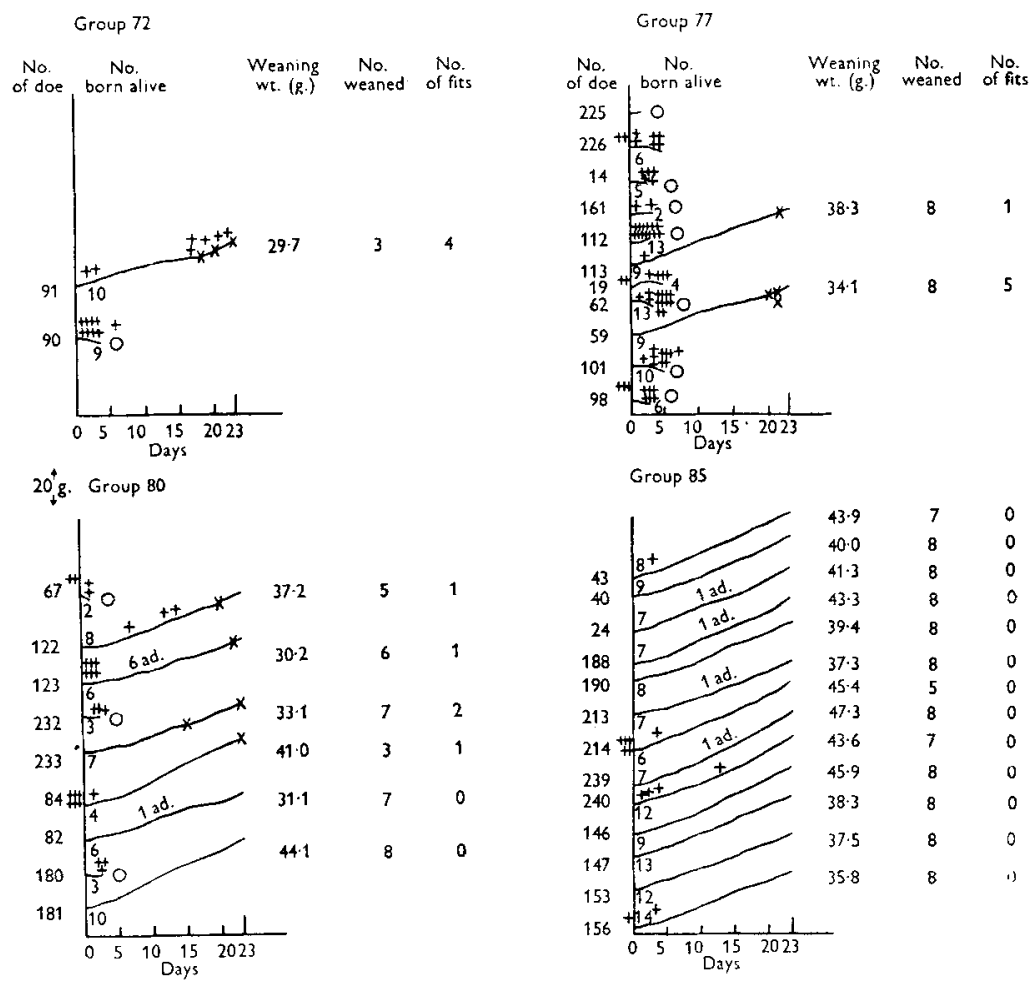

Fig. 6. Third generation. Effect on reproduction and lactation of varying the extraction rate of flour in a diet high in vitamin $B_{1}$. Graphs show average weight per rat from birth onwards for individual litters (daily weighings).* Ad. adopted. + above the graph denotes death of a suckling, stillbirths being indicated by + to left of vertical axis. $x$ denotes fits in sucklings, each $\times$ representing three fits or fewer. The average weaning weight, number of young reared, and total number of fits observed, are shown to the right of each graph.

* See footnote to Fig. 4.

one litter of three rats was reared. Apart from the failure of group 72 , the most striking point in the third generation tests was the almost complete failure of group 77. In the preceding generation this group had appeared equal in breeding performance to group 80 , or even slightly superior to it, but in the third generation only two litters were reared from eleven does. The failure was not primarily in reproduction, for only one doe failed to produce a litter. The remaining eight produced litters with a total of fiftynine live young, none of which survived beyond the first few days. Group 80 showed little further deterioration from its performance in the second generation, six litters 
being reared from nine does. Group 85 maintained its good record; again none of the does failed to rear a litter. Thirteen litters averaging 7.6 rats/litter, with an average weaning weight of $4{ }^{1} \cdot 5 \mathrm{~g}$., were reared, all without fits. Group 72 plus pyridoxin was little better in performance than group 80, except that no fits were observed in the six litters which were reared from eleven does. The failures were again mainly due to the form of cannibalism previously described. It seems probable that the deterioration evident in this group was due to deficiencies of vitamin B-complex factors other than pyridoxin.
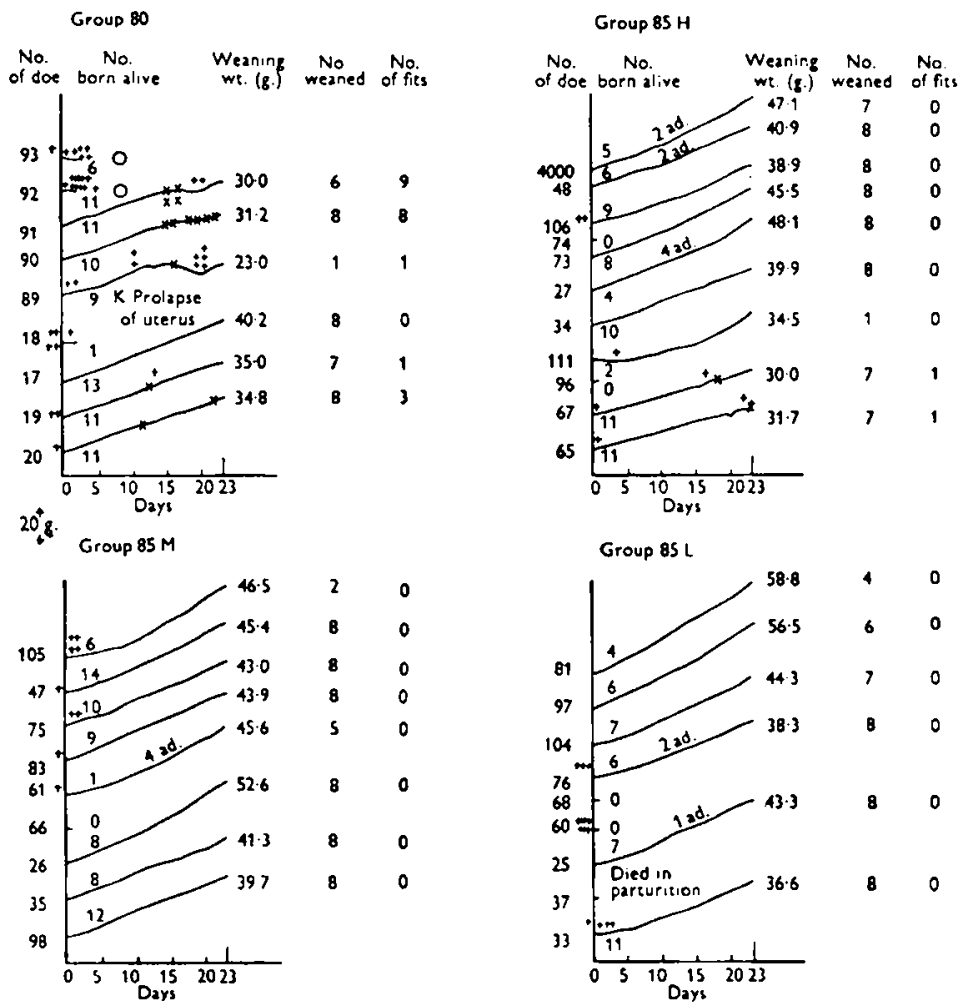

Fig. 7. Fourth-generation breeding records for groups receiving 80 and $85 \%$ extraction flour in a diet high in vitamin $B_{1}$. In groups $85 \mathrm{M}$ and $85 \mathrm{~L}$ litter-mates of animals used in group $85 \mathrm{H}$ were given medium and low intakes of vitamin $B_{1}$ instead of the high intake of group $85 \mathrm{H}$. (Group $85 \mathrm{H}=5.08$, group $85 \mathrm{M}=0.75$, and group $85 \mathrm{~L}=0.27 \mathrm{mg} . / 100 \mathrm{~g}$. diet.) Graphs show average weight per rat from birth onwards for individual litters (daily weighings). Ad. adopted. + above the graph denotes death of a suckling, stillbirths being indicated by + to left of vertical axis. $X$ denotes fits in sucklings, each $x$ representing three fits or fewer. The average weaning weight, number of young reared, and total number of fits observed, are shown to the right of each graph.

- See footnote to Fig. 4.

\section{Fourth generation}

Fourth generation tests were carried out only for groups 80,85 and 72 plus pyridoxin, insufficient animals being available in groups 72 and 77 . All these three groups gave evidence of some deterioration in the fourth generation compared with the third, but none to the degree which had evinced itself in groups 72 and 77 by the third generation (Figs. 7 and 8). In group 80 the increased degeneration was quite marked 
Although the same number of litters, six out of nine born, was reared as in the preceding generation, the number of fits observed was considerably greater. The average weaning weight was somewhat reduced also. Even group $85(85 \mathrm{H})$ showed a distinct falling off from its record in the third generation. Of ten does mated, two failed to produce litters; two others, which were litter-mates, reared very poor litters with mean
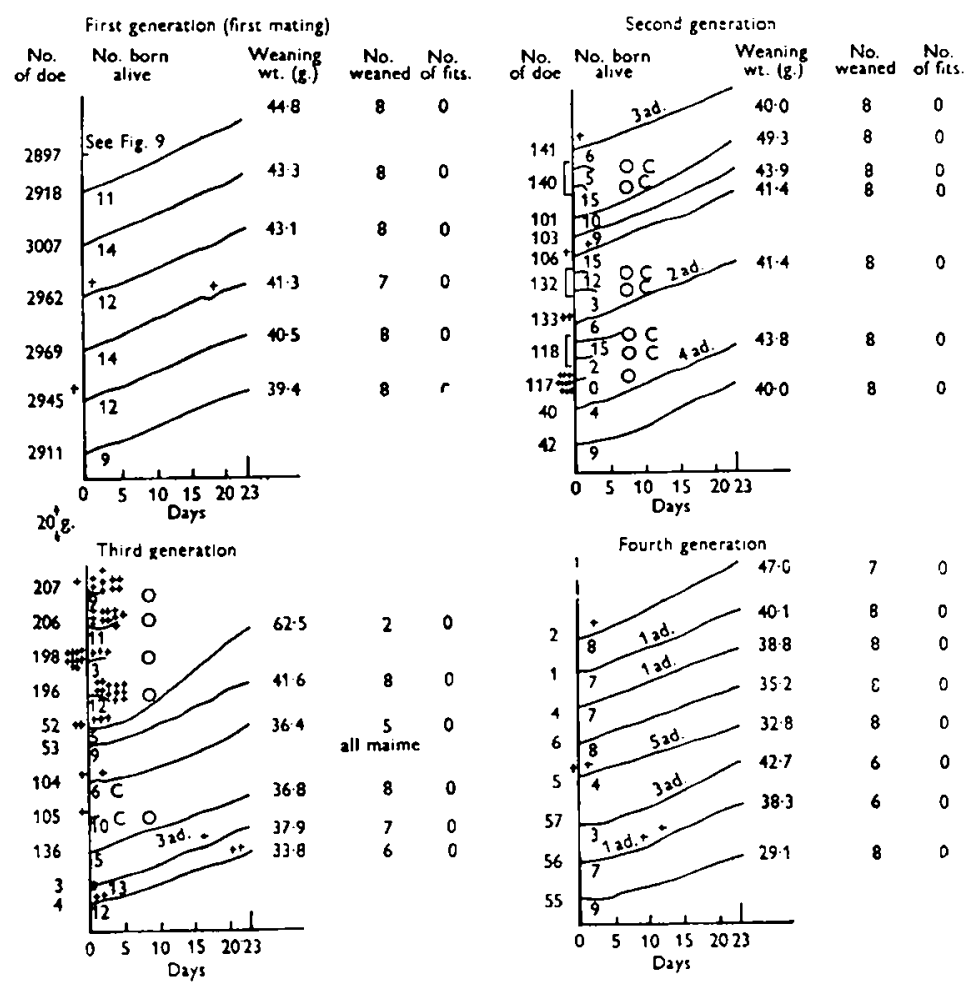

Fig. 8. Reproduction and lactation records for four generations of rats receiving $40 \mu$ g. pyridoxin per head daily as supplement to a diet with $72 \%$ extraction flour and high in vitamin $\mathbf{B}_{\mathbf{1}}$. Graphs show average weight per rat from birth onwards for individual litters (daily weighings). * Ad. adopted. + above the graph denotes death of a suckling, stillbirths being indicated by + to left of vertical axis. $X$ denotes fits in sucklings, each $x$ representing three fits or fewer. $C$ denotes cannibalism. The average weaning weight, and number of young reared, are shown to the right of each graph.

- See footnote to Fig. 4.

weaning weights of $30-3^{\mathrm{I}} \mathrm{g}$., and in each of these litters fits were observed once. The number born alive per litter, and the mean weaning weight of the group, were both less than in the third generation test. In group 72 plus pyridoxin, the breeding record (Fig. 8) appears at first sight considerably better than in the third generation, but this is mainly due to the absence of cannibalism in the fourth generation. The smaller number born alive per litter, and a slight reduction in the mean weaning weight, are indicative of some deterioration. In the fourth generation the highest numbers in the litters were seven to nine whereas, in the third generation, seven of eleven litters had nine to thirteen born alive.

Comparison of the growth and breeding records of group 72 plus pyridoxin and 
group 80 brings out clearly the unreliability of the growth test as an index of the adequacy of a diet for breeding purposes. In the fourth generation test, group 72 plus pyridoxin, which in the growth test was far behind group 80 , in breeding performance proved far ahead of it, and was indeed rather better than group 85 .

Effect of reducing the vitamin $B_{1}$ intake on the breeding performance of fourth generation rats. Comparison of the breeding records of the subgroups $85 \mathrm{H}, 85 \mathrm{M}$ and $85 \mathrm{~L}$ with relatively high, medium and low additions of vitamin $B_{1}$, respectively, shows that it was possible, by reducing the high vitamin $B_{1}$ addition, to effect an improvement even in animals which had been subjected for several generations to the effect of excess vitamin $\mathrm{B}_{1}$ (Table 4 ). Group $85 \mathrm{M}$, with medium vitamin $\mathrm{B}_{1}$ addition, was considerably better than group $85 \mathrm{H}$ with high vitamin $B_{1}$ addition. In group $85 \mathrm{M}$ one doe of nine mated failed to produce a litter, but the other eight each reared a litter, all without fits. The number born alive per litter was greater, and the mean weaning weight was $5 \mathrm{~g}$. higher, than in group $85 \mathrm{H}$. Group $85 \mathrm{~L}$, with low vitamin $\mathrm{B}_{1}$ addition, was less successful than the group with medium vitamin $B_{1}$ addition. Six litters were reared without fits, but there were three failures. The number born alive per litter was smaller, and the weaning weight for litters of seven or eight was lower, than in group $85 \mathrm{M}$. Here again the results of the breeding test did not tally with those of the growth test (Figs. 2 and 3 ), in which group $85 \mathrm{~L}$ was superior to group $85 \mathrm{M}$.

\section{Weight of the thymus gland of weanlings}

The weights of the thymus glands of weanlings were determined whenever possible in all the experiments described in this paper. Table 5 summarizes the results for the four generations, including the three successive matings of the first generation, and the three subgroups having $85 \%$ extraction flour with a range of vitamin $B_{1}$ supplements in the fourth generation. The values for the animals of the first generation show the low weights in group 72 , in which the conditioned pyridoxin deficiency was most severe, and the tendency for the weights to increase with the rising rate of extraction of the flour. The low values in group 72 are in accordance with those previously found in pyridoxin-deficient animals (Richards, 1949). It is known that vitamin B-complex factors other than pyridoxin affect the development of the thymus after weaning, and the higher weights found in groups 77,80 and 85 may be due partly to the influence of increased amounts of these other factors, but the values found in group 72 plus pyridoxin suggest a specific effect of pyridoxin in promoting the development of the thymus before weaning.

The thymus weights for the second generation differed little from those of the first generation, but in the third generation there was a definite decrease in group 77 , and also in group 72 plus pyridoxin. In the fourth generation there was a marked decline in the thymus weights of group 85 , and a considerable decline also in groups 80 and 72 plus pyridoxin. The evidence from the thymus weights thus confirms the conclusion drawn from the breeding records that there was a definite deterioration between the third and fourth generations in all groups.

It is of interest to note that reduction of the vitamin $B_{1}$ addition to the medium level 
led to an increase in the weight of the thymus gland in the fourth generation rats on the $85 \%$ extraction flour diet, the average value for seven litters in subgroup $85 \mathrm{M}$ being $303 \mathrm{mg}$./roo g. body-weight, compared with $24 \mathrm{I} \mathrm{mg}$. for the corresponding subgroup ${ }_{5} \mathrm{H}$ with the high vitamin $B_{1}$ addition. A still greater increase, which brings out the contrast between the thymus weights of the first and fourth generations having the high vitamin $B_{1}$ intake, was found with the litter of doe 4000 . This was a stock weanling,

Table 5. Average weight of the thymus gland of weanlings for four generations of rats receiving diets containing flours of different rates of extraction and with a supplement of $5.08 \mathrm{mg}$. vitamin $B_{1} / 100 \mathrm{~g}$. diet except for the fourth generation receiving $85 \%$ flour, where the group was subdivided to receive the same or two smaller amounts of vitamin $B_{1}$ as shown in the lower half of the table

(Thymus glands of weanlings weighing less than $3 \circ \mathrm{g}$. have been excluded.)

Average weights of thymus glands of weanlings in groups receiving flours of various rates of extraction (mg./100 g. body-wt.)

$\begin{array}{lc}\text { Gene- } & \\ \text { ration } & \text { Mating } \\ \text { no. } & \text { no. } \\ \text { I } & \text { I } \\ & 2 \\ & 3 \\ 2 & \text { I } \\ 3 & \text { I } \\ 4 & \text { I }\end{array}$

$\begin{array}{ccccc}72 \% & 77 \% & 80 \% & 85 \% & \begin{array}{c}72 \%+ \\ \text { pyridoxin }\end{array} \\ 221(6,22)^{*} & 294(7,36) & 306(6,40) & 322(8,55) & 332(6,35) \\ 216(6,20) & 293(7,27) & 260(8,35) & 326(8,26) & 341(6,17) \\ 231(7,42) & 321(7,52) & 284(8,58) & 318(7,55) & 361(5,40) \\ 198(2,3) & 298(8,25) & 279(4,15) & 331(12,61) & 346(7,31) \\ 249(1,3) & 273(2,16) & 285(3,12) & 314(11,38) & 316(4,23) \\ \text { No litters } & \text { No litters } & 249(5,28) & 241(7,33) & 285(8,43)\end{array}$

Subgroups of group with $85 \%$ extraction flour

\begin{tabular}{|c|c|c|c|c|c|}
\hline \multirow[b]{2}{*}{$\begin{array}{l}\text { Genera- } \\
\text { tion no. }\end{array}$} & \multirow[b]{2}{*}{$\begin{array}{l}\text { Mating } \\
\text { no. }\end{array}$} & \multirow[b]{2}{*}{ Subgroup } & \multicolumn{2}{|c|}{ Vitamin $B_{1}$ supplement } & \multirow[b]{2}{*}{$\begin{array}{l}\text { Average thymus wt. } \\
\text { (mg./100 g. body-wt.) }\end{array}$} \\
\hline & & & Level & $\mathrm{mg} / 100 \mathrm{~g}$. diet & \\
\hline & $\mathbf{I}$ & $8_{5} \mathrm{H}+$ & High & $5 \cdot 08$ & $241(7,33)$ \\
\hline 4 & $\mathbf{I}$ & $85 \mathrm{M}$ & Medium & 0.75 & $303(7,40)$ \\
\hline & $\mathbf{I}$ & $85 \mathrm{~L}$ & Low & 0.27 & $277(6,35)$ \\
\hline $\mathbf{I}$ & $\mathbf{I}$ & Stock $\downarrow$ & High & 5.08 & $332(1,7)$ \\
\hline
\end{tabular}

- The figures in parentheses give the number of litters and weanlings for which the average is calculated.

$\dagger$ Same data as for fourth generation of $85 \%$ flour group above.

I A weanling (no. 4000) bred on stock diet was weaned, reared and mated at the same time and on the same experimental diet, with high vitamin $B_{1}$ supplement, as the fourth generation rats of the $85 \%$ extraction flour group.

reared and mated together with the fourth generation animals in subgroup $85 \mathrm{H}$, with the high vitamin $B_{1}$ addition, which was the same as that given throughout in group 85 . It was thus a first generation animal, and the thymus weight obtained for its litter, $332 \mathrm{mg}$. $/ 100 \mathrm{~g}$. body-weight, was in agreement with the values of 322,326 and $318 \mathrm{mg}$. obtained for group 85 in the three matings of the first generation. Further, the weaning weight of $47^{\cdot 1} \mathrm{~g}$. for the litter of doe 4000 was much greater than the average of $39 \cdot 3 \mathrm{~g}$. found for the fourth generation litters in this group, and was comparable with the weights of $44^{\circ} 8,49^{\circ} \mathrm{O}$ and $49^{\circ} 2 \mathrm{~g}$. obtained from the three matings of the first generation rats in the group. 


\section{DISCUSSION}

From a survey of the breeding tests for the four generations it is evident that the conditioned pyridoxin deficiency caused by the high vitamin $B_{1}$ addition, which was very severe on the diet with $72 \%$ extraction flour, decreased in intensity with the rising rate of extraction of the flours. With each succeeding generation there was a progressive deterioration in the breeding performance of the groups on 72,77 and $80 \%$ extraction flour until, by the third generation, the first two groups had almost ceased to exist, whereas the group on $85 \%$ extraction flour showed little sign of deterioration. By the fourth generation deterioration had begun to show even in this group, and confirmation that the deterioration was largely due to excessive intake of vitamin $B_{1}$ was given by the improvement effected in the breeding records and thymus weights, even of these fourth generation animals, by reducing it.

One of the most striking evidences of the deterioration in breeding performance was the number of early deaths in the litters. Although the number of stillborn in the groups which showed most rapid deterioration tended to increase, this was less marked than the increase in the number of young which died during the early days of lactation. It has recently been suggested (Sica \& Cerecedo, 1948) that the survival of newborn rats, regardless of diet, depends largely on the birth weight, and that below the critical range of $5.0-5.4 \mathrm{~g}$. chance of survival is small. It is certainly true that weaklings below $5 \mathrm{~g}$. at birth seldom survive, but in the present experiments the birth weights of the litters which failed to survive beyond the first few days were for the most part fairly normal. In only $13 \%$ of the litters did the birth weight fall below $5.0 \mathrm{~g}$. and in $73 \%$ it ranged from 5.4 to $6.5 \mathrm{~g}$., with an average of $5.8 \mathrm{~g}$. Lack of maternal instinct and failure in lactation are unsatisfying explanations of such deaths, for it is unusual for a rat having an adequate diet to fail in this way. Moreover, these explanations do not agree with some of the observed facts. Thus, doe 123 in the third generation of group 80 , which produced a litter of six young apparently quite healthy and averaging $6.5 \mathrm{~g}$. at birth, failed to rear them, but reared six other adopted ones. Four of these belonged to the litter of doe 147 in group 85 , which still showed no sign of deterioration, and the remaining two were from doe 181, the only animal in group 80 which reared an apparently normal litter. Doe 123 was thus not lacking in maternal instinct or ability to suckle young, and the facts suggest some inborn defect in her young making them nonviable. The occurrence of fits in adults of the second generation suggests the possible presence, even in the litters of the first generation, of defects which might account for the large number of early deaths in the litters of the second and third generations.

The deaths which took place in the second half of the suckling period, generally in litters subject to fits, also would appear to be due to defects in the young, arising presumably in the course of lactation. The evidence points to deficiency in the quality rather than the quantity of the doe's milk, for it was often observed when the young were dying that milk, which the young were apparently unable to use, accumulated about the teats of the doe. This deficiency in quality was made good in most cases by administration of pyridoxin to the doe, but the anomalous behaviour of two litters in the 72 plus pyridoxin group suggests the influence of some other deficiency 
(Fig. 9). Thus, at the first mating, doe 2897 seemed to rear her litter normally for 15 days, but seven of the young died between 15 and 18 days, with no sign of fits. Post-mortem examination showed that the stomachs of the young rats were packed with a firm mass of curd. The one survivor which reached weaning showed one fit on the 2oth day, in spite of the fact that the doe was receiving pyridoxin. This suggests that there had been some defect of absorption in this litter from some unknown cause. In

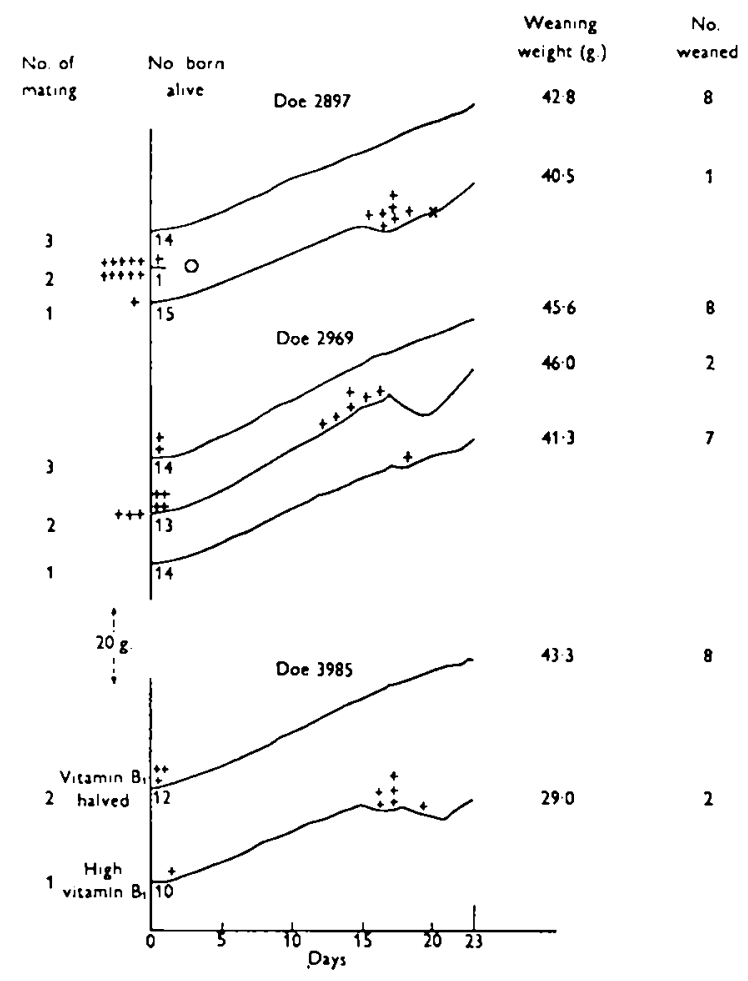

Fig. 9. Anomalous behaviour of three litters from does receiving a daily supplement of $40 \mu \mathrm{g}$. pyridoxin from weaning onwards, with a diet of $72 \%$ extraction flour and high in vitamin $B_{1}$. Deaths of sucklings suggest deficiency of some other factor of the vitamin B complex. Does 2897 and 2969 were first generation rats. Doe 3895 is derived from the experiment in which individual $B$-vitamins were added to the diet, as described in the previous paper (Richards, 1949). Graphs show average weight per rat from birth onwards for individual litters (daily weighings).* + above the graph denotes death of a suckling, stillbirths being indicated by + to left of vertical axis. $x$ denotes the occurrence of one fit. The average weaning weight and the number of young reared are shown to the right of each graph.

$$
\text { - See footnote to Fig. } 4 .
$$

the second mating, doe 2897 produced a litter of ten stillborn young and one living one which died on the xst day. At the third mating, she produced fourteen young alive, and reared a normal litter of eight. This improvement in the third litter was in keeping with the general improvement noted at the third mating of the first generation rats.

Doe 2969 , also in the 72 plus pyridoxin group, succeeded in rearing her first litter reasonably well, although there was one death at 19 days, but at the second mating six of the litter died between $\mathrm{I} 3$ and $\mathrm{I} 7$ days, with no fits; the steadily rising weight of the young during this period would seem to be against any 
deficiency in the quantity of the doe's milk. Again there was a mass of curd in the stomachs of the dead rats, though it was less hard in consistency than in the previous case. A third instance of similar deaths was found in the experiment with individual B-vitamins recently reported (Richards, 1949), and the weight graphs are reproduced in Fig. 9 (doe 3985).

In one of his earlier studies on dietary requirements for lactation, Sure (1928) demonstrated the inefficiency of the lactating doe in secreting 'vitamin B' in the milk, and described the symptoms in young rats arising from an insufficient supply of yeast extract. At that time the vitamin $B$ complex had not been split into its numerous factors, though evidence had accumulated of its 'dual' nature. The symptoms described by Sure, of posterior paralysis, muscle chills, and screaming running fits, thus, really represent more than one deficiency. He found that the nursing young at the point of death had their stomachs well distended with curd, and suggested (p. 698) that the convulsions might be 'due to a gastritis produced by the undigested curd irritating the gastric mucosa'. It is now known that the convulsive fits are due to pyridoxin deficiency, but the mass of curd has been found in the stomachs of rats whose mother received pyridoxin. Hence it seems more probable that the deaths in both Sure's experiments and those reported here were caused by deficiency of some other factor of the vitamin B complex. So far no other reference has been found to the subject, and no suggestion is offered as to the responsible missing factor.

From these flour experiments it is clear that growth tests alone are not sufficient for assessing the nutritive value of a diet. The added strain of lactation will often show up unsuspected deficiencies, and it would appear that experiments to the third and fourth generations may be necessary to test the complete adequacy of a diet for the satisfactory performance of all physiological functions. The experiments indicate also the superiority of $85 \%$ extraction flour over flours of lower extraction in counteracting deficiencies or imbalances of B-vitamins in a diet. Even with an excessive intake of vitamin $B_{1}$, the diet containing $85 \%$ extraction flour was almost adequate for the fourth generation, and it is suggested that with a smaller intake of vitamin $B_{1}$ this diet would be excellent for maintaining good growth and reproduction in laboratory animals.

\section{SUMMARY}

I. Rats were fed for four generations on diets containing $6 \mathrm{I} \%$ of wheat flour of 72 , 77,80 and $85 \%$ extraction, to which was added an excess of vitamin $B_{1}$. Previous work had shown that when this diet contained flour of approx. $70 \%$ extraction, a state of conditioned pyridoxin deficiency was induced, which manifested itself in the litters by failure in growth, by the occurrence of fits, by the death of the young, and by a low weight of the thymus gland in the survivors.

2. As the extraction rate of the flour in the diets was increased, the severity of the pyridoxin deficiency was diminished, improvement being shown by reduction in the number of fits in the sucklings and by increase in the weaning weights.

3. With the flour of $72 \%$ extraction the breeding performance was so bad that in the second generation scarcely any animals were available for a third generation test. 
With the $77 \%$ extraction flour the breeding performance deteriorated in the second generation and failed almost completely in the third, when most of the litters died within a few days of birth.

With the $80 \%$ extraction flour there was progressive deterioration to the fourth generation, but it was not as great as in the earlier generations of rats having the flours of lower extraction rate.

With the $85 \%$ extraction flour an excellent breeding record was maintained for three generations and no signs of deterioration were apparent till the fourth generation.

4. Reduction of the vitamin $B_{1}$ intake in a part of the group having $85 \%$ extraction flour considerably improved the state of the fourth generation animals.

5. The thymus glands of weanlings having the $72 \%$ extraction flour diet showed, even in the first generation, the low weight characteristic of pyridoxin deficiency.

The thymus weights increased with the rising extraction rate of the flour. In the third and fourth generations the low values for the thymus weight in the surviving groups confirmed the evidence of deterioration afforded by the breeding records.

Reduction of the vitamin $B_{1}$ intake of the fourth generation rats having the $85 \%$ extraction flour resulted in increased thymus weights.

6. When pyridoxin was given to does having $72 \%$ extraction flour, the young did not have fits, and their weaning and thymus weights were higher. With this addition fairly good breeding was maintained through the second, third and fourth generations, though some of the data suggest a deficiency of other B-vitamins, also possibly conditioned by the excessive intake of vitamin $B_{1}$.

7. The results emphasize the unreliability of assessing the nutritive value of a diet by growth tests alone. To ensure that a diet is adequate for the performance of all physiological functions, breeding tests to the third and fourth generation, or even beyond this, may be required.

I desire to thank Dr James Sword, Cereal Laboratory, Scottish Co-operative Wholesale Society, for supplying the samples of wheat flour used in these experiments.

\section{REFERENCES}

Mellanby, E. (1946). Brit. med. F. ii, 885 .

Mellanby, E. (1947). Brit. med. F. ii, 288.

Richards, M. B. (1945). Brit. med. F. i, 433.

Richards, M. B. (1946). Nature, Lond., r58, 306.

Richards, M. B. (1947). Biochem. Y. 41, xliii.

Richards, M. B. (1949). Brit. F. Nutrit. 3. 109.

Sica, A. J. \& Cerecedo, I. R. (1948). Science, 107, 222.

Sure, B. (1928). F. biol. Chem. 76, 685. 